\title{
Evaluation of Pyrosequencing Method for a BRAFV600E Mutation Test
}

\author{
Seo Young $\mathrm{Oh}^{1,2}$ and Hoon Taek Lee ${ }^{2}$ \\ ${ }^{1}$ Department of Pathology, Konkuk University Medical Center, Seoul 143-729, Korea \\ ${ }^{2}$ Department of Animal Biotechnology, College of Animal Bioscience \& Technology Konkuk University, Seoul 143-729, Korea
}

\begin{abstract}
A fine needle aspiration biopsy (FNAB) is the primary means of distinguishing benign from malignant in thyroid nodules. However, between 10 and $30 \%$ of the FNABs of thyroid nodules are diagnosed as 'indeterminate'. A molecular method is needed to reduce unnecessary surgery in this group. In Korea, most thyroid cancer is classic papillary type and BRAFV600E mutation is highly prevalent. Thus, this study compared the pyrosequencing method with the conventional direct DNA sequencing and PCR-RFLP analysis and investigated the evaluation of preoperative BRAFV600E mutation analysis as an adjunct diagnostic method with routine FNABs. Sixty-five (78.3\%) of 83 histopathologically diagnosed malignant nodule revealed positive BRAFV600E mutation on pyrosequencing analysis. In detail, $65(83.8 \%)$ of 78 papillary thyroid carcinomas sample showed positive BRAFV600E mutation. None of 29 benign nodules had in pyrodequencing, direct DNA sequencing and PCR-RFLP. Out of 31 thyroid nodules classified as 'indeterminate' on cytological examination preoperatively, 28 cases turned out to be malignant: 24 papillary thyroid carcinomas. Among that, 16 (66.7\%) classic papillary thyroid carcinomas had BRAFV600E mutation. Among 65 papillary thyroid carcinomas with positive BRAFV600E mutation detected by pyrosequencing analysis, each 3 cases and 5 cases did not show BRAFV600E mutation by direct DNA sequencing and PCR-RFLP analysis. Therefore, pyrosequencing was superior to direct DNA sequencing and PCR-RFLP in detecting the BRAFV600E mutation of thyroid nodules ( $p=0.027$ ). Detecting BRAFV600E mutation by pyrosequencing was more sensitivity, faster than direct DNA sequencing or PCR-RFLP.
\end{abstract}

Keywords: BRAFV600E, FNAB, Thyroid nodule, Papillary thyroid carcinomas

This is an Open Access article distributed under the terms of the Creative Commons Attribution Non-Commercial License (http://creativecommons.org/licenses/by-nc/3.0) which permits unrestricted non-commercial use, distribution, and reproduction in any medium, provided the original work is properly cited.

Copyright () 2015 The Korean Society for Clinical Laboratory Science. All rights reserved.
Corresponding author: Seo Young Oh Department of Pathology, Konkuk University Medical Center, Seoul 143-729, Korea Tel: 82-2-2030-5631

E-mail:syoh@kuh.ac.kr

Received: February 27, 2015

Revised: March 17, 2015

Accepted: March 18, 2015

\section{서 론}

갑상선암의 초기 증상은 갑상선 결절 형태로 나타나며, 약 5 $20 \%$ 가 촉진 가능한 갑상선 결절을 갖고 있다는 보고가 있다 (Ezzat et al., 1994; Meier et al., 2000; Kang et al., 2004). Lee 등(2003) 은 갑상선 결절을 고해상도 초음파진단법으로 검사했을 때, $35.3 \%$ 가 갑상선 우연종으로 진단되고, 이러한 갑상선 우연종의 $3.5 \%$ 는 악성으로 밝혀질 확률이 높다고 보고하였다. 그리고 고해상도 초음 파진단법으로 밝혀진 갑상선 우연종은 세침흡인 세포검사에서 갑 상선암과 양성 결절로 진단 분류되고 있다(National Cancer Centre, 2003). 그러나 세침흡인 세포검사는 시료 보관 상태에 따 른 세포 형태의 변성으로 불확실한 진단을 하게 되고, 그 결과 반복
된 세침흡인 세포검사 및 불필요한 외과적 간섭이 발생한다고 하였 다(Kim et al., 2006). 그리고 진단이 불확실하거나 소포형 증식성 결절인 경우, 수술에 따른 이환율이 높다고 하였다(Haugen et al., 2002; Oertel et al., 2002).

갑상선 결절 검사의 가장 중요한 목적은 세포의 악성 여부를 확 인하는 것이다. 갑상선 결절 검사를 위한 여러 검사법들 중에서 특 히 세침흡인 세포검사는 임상소견이나 영상소견에 비하여 높은 예 측도를 제공하며, 간편하고 안전한 검사법으로 보고되었다(Oertel et al., 2002). 그러나 세침흡인 세포검사는 악성종양을 진단하는데 매우 중요한 정보를 제공하지만 10 30\%는 갑상선암과 양성 결절 성 증식을 감별하지 못하는 불확실한 소견을 보여, 임상 의사들이 치료방침을 결정하는데 혼동을 준다고 하였다(Kim et al., 2006). 
이런 문제를 해결하기 위하여 갑상선암 진단에 분자유전학적인 연 구가 도입되었고, $\mathrm{BRAF}^{\mathrm{V}}{ }^{\mathrm{V} 00 \mathrm{E}}$ 돌연변이 유전자는 갑상선에서 발생 하는 종양 중에서 유두암, 특히 유두암 종류에서도 분화가 나쁜 암 종에 국한되어 관찰되며, 양성 결절이나 소포형에서는 관찰되지 않 으므로 갑상선 유두암 진단에 유용한 유전자로 알려져 있다(Jarry et al., 2004; Kim et al., 2008).

BRAF는 RAF의 세 이형체(A, B, and C)의 하나로 세린/트레오 닌 카이네이즈를 암호화하는 단백질이며 RAS와 결합하여 신호를 조절한다(Davies et al., 2002). BRAF 유전자의 T1799A 돌연변이 는 단백질 산물에서 $\mathrm{V} 600 \mathrm{E}$ 로 아미노산 치환을 하고, 치환된 아미 노산은 BRAF 카이네이즈를 활성화하여 갑상선 유두암의 발암을 유발하는데 중요한 역할을 한다(Kimura et al., 2003). 최근 갑상선 유두암의 BRAF 연구에서 활성화 점 돌연변이의 빈도는 유두암의 29 69\%로 나타난다고 보고하였고(Xing et al., 2005), 요오드 섭 취가 많은 한국인의 갑상선 유두암에서 $\mathrm{BRAF}^{\mathrm{V} 600 \mathrm{E}}$ 돌연변이 빈도 는 서구에 비하여 73 86\%로 훨씬 높게 보고되었다(Kim et al., 2004; Kim et al., 2006; Chung et al., 2006). 따라서 Chung 등 (2006)은 $\mathrm{BRAF}^{\mathrm{V} 600 \mathrm{E}}$ 돌연변이 유전자를 한국인 갑상선 유두암의 진단 표지자로 볼 수 있으며 전통적인 세침흡인 세포검사와 $\mathrm{BRAF}^{\mathrm{V} 600 \mathrm{E}}$ 돌연변이 분자진단법의 병행이 필요하다고 보고하였 다.

$\mathrm{BRAF}^{\mathrm{V} 600 \mathrm{E}}$ 돌연변이 분자진단법은 보편적으로 직접염기서열 분석법이 사용되고 있으며(Mane et al., 1990), 직접염기서열 분석 법은 돌연변이체와 야생형이 혼재 되어있는 시료인 경우, 20 $25 \%$ 이상의 돌연변이체가 포함되어야 정확한 분석이 가능하고, 또 한 분석비용과 시간 그리고 노동력이 많이 소모되는 분석법으로 이 용에 제약이 있다고 하였다(Mane et al., 1990).

$\mathrm{BRAF}^{\mathrm{V} 600 \mathrm{E}}$ 돌연변이 분석의 정확성을 높이기 위하여 Agaton 등 (2002)과 소수의 다른 연구자들은 SNP (Single nucleotide polymorphism)방식으로 돌연변이를 분석하는 새로운 염기서열 분석법인 pyrosequencing 분석법에 대한 연구를 시행하였고, pyrosequencing 분석법은 여러 가지 면에서 직접염기서열 분석 법과 다르다고 하였다(Fakhrai-Rad et al., 2002; Garcia et al., 2000; Ronaghi et al., 1998). 따라서, 본 연구는 갑상선 결절 검사 에서 $\mathrm{BRAF}^{\mathrm{V}}{ }^{600 \mathrm{E}}$ 돌연변이 유전자가 갑상선 유두암 감별 진단에 유 용한 진단 표지자임을 확인하고, pyrosequencing 분석법의 민감 도, 특이도 및 정확도를 직접염기서열 분석법 및 PCR-RFLP 분석 법과 비교하였다. 그리고 pyrosequencing 분석법이 갑상선 유두 암 진단 표지자로 인식되고 있는 $\mathrm{BRAF}^{\mathrm{V} 600 \mathrm{E}}$ 돌연변이 분석에 유용 한 분자진단 검사법임을 확인하고자 본 연구를 실시하였다.

\section{재료 및 방법}

\section{1. 세포 시료}

본 연구는 건국대학교병원 임상연구심의위원회에서 승인 (KUH1210002)을 얻은 세포시료를 이용하여 연구하였다. 건국대 학교병원의 외과병리기록파일을 조사하여 2010년 8월부터 2012 년 3월까지 수술로 갑상선 결절이 절제된 환자들을 선별하였다. 1 차 환자 선별 후, 세포검사는 선별된 환자의 세침흡인 세포검사 슬 라이드를 숙련된 병리학자에 의해 재조사하여 세포학적으로 진단 하였다. 그리고 분자진단법 비교 연구는 세포검사와 같은 세침흡인 세포를 이용하여 $\mathrm{BRAF}^{\mathrm{V} 600 \mathrm{E}}$ 돌연변이를 분석하였다. 시료는 최종 조직병리학적 진단이 완료된 갑상선 유두암 56예, 양성 26예 그리 고 불확실한 군 31 예 등 총 113 예를 이용하여 분석하였다.

\section{2. 세포주를 이용한 민감도 분석}

$\mathrm{BRAF}^{\mathrm{V} 600 \mathrm{E}}$ 돌연변이 검출의 민감도 분석을 위하여 $\mathrm{BRAF}^{\mathrm{V} 600 \mathrm{E}}$ 돌 연변이가 존재하는 것으로 알려진 유두암 세포주 SNU-790과 $\mathrm{BRAF}^{\mathrm{V}}{ }^{600 \mathrm{E}}$ 돌연변이가 없는 세포주 $\mathrm{SNU}-216$ 을 한국 세포주 은행 으로부터 제공받아 핵산을 추출하였다. SNU-790 세포핵산을 SNU-216 세포핵산에 $0 \%$ 에서 $100 \%$ 까지 세포핵산을 희석하여 pyrosequencing 분석법, 직접염기서열분석법 그리고 PCR-RFLP 분석법으로 시행하였다.

\section{3. 핵산 추출}

세침흡인 시료의 세포학적 진단을 위하여 제작된 유리슬라이드 에서 커버 슬라이드를 제거한 후, $26 \mathrm{Gage}$ 주사바늘을 이용하여 갑 상선 이상세포만 긁어내었다. 긁어낸 세포를 $10 \%$ Resin이 함유된 $30 \mu \mathrm{L}$ 의 핵산 추출 완충액 $(50 \mathrm{mM}$ Tris 완충액, $\mathrm{pH} 8.3 ; 1 \mathrm{mM}$ EDTA, pH 8.5; 5\% Tween 20)에 넣고, $100 \mu \mathrm{g} / \mathrm{mL} \mathrm{PK}$ (Proteinase $\mathrm{K}$ )를 처리하여 세포가 완전히 녹을 때까지 $56^{\circ} \mathrm{C}$ 에서 반응하였다. 그 후에 튜브를 $100^{\circ} \mathrm{C}$ 에서 10 분 동안 가열하여 $\mathrm{PK}$ 를 불활성화 시키고, $13000 \mathrm{rpm}$ 에서 10분 동안 원심분리하여 핵산 이 포함되어 있는 상층액 $5 \mu \mathrm{L}$ 를 중합효소연쇄반응에 사용하였다 (Oh et al., 2014).

\section{Pyrosequencing 분석법}

Pyrosequencing 분석은 $\mathrm{BRAF}$ 돌연변이 분석을 위하여 정방향 프라이머 5'-biotin-CTTCATAATGCTTGCTCTGATAGG-3'와 역 방향 프라이머 5'-GGCCAAAAATTTAATCAGTGGAA-3'를 사용 하였고, BRAF 유전자 엑손 15의 T1799A 돌연변이가 예상되는 부 위를 중합효소연쇄반응으로 증폭하였다. 중합효소연쇄반응 혼합 
액은 $20 \mathrm{pmol}$ 의 정방향과 역방향 프라이머, $0.2 \mathrm{mmol} \mathrm{dNTP,} 1.5$ $\mathrm{mmol} / \mathrm{L} \mathrm{MgCl}_{2}, 1 \times \mathrm{PCR}$ buffer, $1.5 \mathrm{U}$ Immolase DNA polymerase (Bioline, London, UK)를 넣어 제조한 후, $5 \mu \mathrm{L}$ 의 핵 산을 넣어 증폭하였다. 반응조건은 $95^{\circ} \mathrm{C}$ 에 10 분간 초기변성 시킨 후, $94^{\circ} \mathrm{C}$ 에서 5 분, $94^{\circ} \mathrm{C}$ 에서 30 초, $55^{\circ} \mathrm{C}$ 에서 30 초, $72^{\circ} \mathrm{C}$ 에서 30 초간 39 cycles을 증폭하고, $72^{\circ} \mathrm{C}$ 에서 5 분간 후기 반응하였다. 중 합효소연쇄반응 결과는 $2 \%$ agarose gel을 이용하여 $217 \mathrm{bp}$ 의 크 기로 증폭된 산물을 확인하였다. Pyrosequencing 분석을 위하여 biotin이 결합된 증폭산물 $20 \mu \mathrm{L}$ 를 Streptavidin-separose bead (Amersham biotechnology, Uppersala, Sweden)가 있는 결합 완충액(Biotage, Uppersala, Sweden)과 혼합하여 실온에서 10분 동안 교반하고, 증폭산물을 bead에 결합시켰다. 증폭산물이 결합 된 Streptavidin-separose bead는 96 마그네틱 이젝터블 마이크 로실린더(Biotage, Uppersala, Sweden)를 포함한 PSQ 96 샘플 프렙툴에 흡착시키고, Streptavidin-separose bead에 결합된 증 폭산물을 변성 및 수세한 후, 염기분석 프라이머가 들어 있는 어닐 링 완충액(Biotage, Uppersala, Sweden)에 bead를 넣고, $80^{\circ} \mathrm{C}$ 에 서 2 분간 변성시켰다. 그 다음 10 분 동안 실온에서 염기분석 프라 이머와 증폭산물이 상보적으로 결합할 수 있도록 한 후, SNP 시약 키트 PSQ96MA System (Biotage, Uppersala, Sweden)을 이용하 여 분석하였다. 분석기계는 PyroMark ID (Biotage, Uppersala, Sweden)를 사용하였고 키트와 기계회사에서 제공된 매뉴얼에 따 라 시행하였다.

\section{5. 직접염기서열 분석법}

직접염기서열 분석은 pyrosequencing 분석과 같은 프라이머 를 사용하여 BRAF 유전자 엑손 15 의 T1799A 돌연변이가 예상되 는 부위를 중합효소연쇄반응으로 증폭하였다. 중합효소연쇄반응 혼합액은 $20 \mathrm{pmol}$ 의 정방향과 역방향 프라이머, $0.2 \mathrm{mmol} \mathrm{dNTP}$, $1.5 \mathrm{mmol} / \mathrm{L} \mathrm{MgCl}, 1 \times \mathrm{PCR}$ buffer, $1.5 \mathrm{U}$ Immolase DNA polymerase (Bioline, London, $\mathrm{UK}$ )를 넣어 제조한 후, $5 \mu \mathrm{L}$ 의 핵 산을 넣어 증폭하였다. 반응조건은 $95^{\circ} \mathrm{C}$ 에 10 분간 초기변성 시킨 후, $94^{\circ} \mathrm{C}$ 에서 5 분, $94^{\circ} \mathrm{C}$ 에서 30 초, $55^{\circ} \mathrm{C}$ 에서 30 초, $72^{\circ} \mathrm{C}$ 에서 30 초간 39 cycles을 증폭하고, $72^{\circ} \mathrm{C}$ 에서 5 분간 후기 반응하였다. 중 합효소연쇄반응 결과는 $2 \%$ agarose gel을 이용하여 $217 \mathrm{bp}$ 의 크 기로 증폭된 산물을 확인하였다. 염기서열 분석은 중합효소연쇄반 응으로 증폭된 산물을 정제한 후, $\mathrm{ABI} 310 \mathrm{DNA}$ analysis system (Applied biosystem, California, USA)을 이용하여 돌연변이를 확 인하였다.

\section{PCR-RFLP 분석법}

PCR-RFLP 분석을 위한 중합효소연쇄반응은 BRAF 유전자 엑 손 15의 T1799A 돌연변이가 예상되는 부위를 정방향 프라이머 5'-TAAAAATAGGTGATTTTGGTCTAGCTCTAG-3'와 역방향 프 라이머 5'-ACTATGAAAATACTATAGTTGAGA-3'를 사용하여 증 폭하였다. 중합효소연쇄반응 혼합액은 $20 \mathrm{pmol}$ 의 정방향과 역방 향 프라이머 $0.2 \mathrm{mmol} \mathrm{dNTP}, 1.5 \mathrm{mmol} / \mathrm{L} \mathrm{MgCl}, 1 \times \mathrm{PCR}$ buffer, 1.5 U Immolase DNA polymerase (Bioline, London, $\mathrm{UK}$ 를 넣어 제조한 후, $5 \mu \mathrm{L}$ 의 핵산을 넣어 증폭하였다. 반응조건 은 $95^{\circ} \mathrm{C}$ 에 10 분간 초기변성 시킨 후, $94^{\circ} \mathrm{C}$ 에서 5 분, $94^{\circ} \mathrm{C}$ 에서 30 초, $54^{\circ} \mathrm{C}$ 에서 30 초, $72^{\circ} \mathrm{C}$ 에서 30 초간 35 cycles을 증폭시켰고, $72^{\circ} \mathrm{C}$ 에서 5 분간 후기 반응한 후, $2 \%$ agarose gel을 이용하여 195 $\mathrm{bp}$ 의 중합효소연쇄반응 산물을 확인하였다. 돌연변이 분석을 위 한 제한효소는 6 개의 염기와 $\mathrm{C} / \mathrm{T}$ 염기를 동시에 인지하여 자르는 XbaI (TAKARA, Shiga, Japan)을 사용하였다. 제한효소 반응액은 $1 \times \mathrm{M}$ buffer, $0.01 \% \mathrm{BSA}, 15 \mathrm{U} / \mu \mathrm{L}$ Xbal $0.5 \mu \mathrm{L}$ 을 혼합하여 제조 하였고, 제조된 제한효소 반응액에 증폭산물 $10 \mu \mathrm{L}$ 를 넣고 $37^{\circ} \mathrm{C}$ 에 서 90분간 반응시킨 후, $7 \%$ acrylamide gel을 이용하여 확인하였 다. 결과는 $\mathrm{BRAF}^{\mathrm{V}}{ }^{600 \mathrm{E}}$ 돌연변이가 존재하는 경우 $195 \mathrm{bp}$ 와 $166 \mathrm{bp}$ 의 위치에서 두 개의 밴드가 나타나고, $\mathrm{BRAF}^{\mathrm{V} 600 \mathrm{E}}$ 돌연변이가 존재 하지 않는 경우에는 $195 \mathrm{bp}$ 위치에서 하나의 밴드만 나타나도록 디 자인 되었다(Hayashida et al., 2004).

\section{7. 통계}

본 검사결과는 $\mathrm{BRAF}^{\mathrm{V} 600 \mathrm{E}}$ 돌연변이에 대한 각 분석방법의 민감 도, 특이도 및 진단 정확도를 확인하기 위하여, TP (true-posivite), $\mathrm{TN}$ (true-negative), FP (false-positive) 및 FN (false-negative) 로 분류하였다. 세침흡인 세포검사의 민감도 및 특이도 분석에서 불확실한 군은 잠재적 악성으로 분류하였다. 그리고 진단검사법의 민감도, 특이도 및 정확도의 통계학적 분석은 SPSS Windows version 16.0 프로그램을 이용하여 ROC (Receiver Operation Characteristic Curve)곡선 통계처리법으로 분석하였다. ROC곡 선은 진단검사방법의 정확도를 평가하는 통계분석법의 하나로, 음 성과 양성을 나누는 기점(Cut off)의 위치에 따라 민감도와 특이도 를 확인할 수 있는 그래프 분석법이다(윤 등, 2002). ROC곡선에서 $p$ value는 0.05 이하인 것을 통계적으로 유의한 것으로 판정하였다.

민감도=\{TP/(TP+FN) $\} \times 100$;

특이도 $=\{\mathrm{TN} /(\mathrm{TN}+\mathrm{FP})\} \times 100$; 
양성 예측치(positive predictive value, PPV)

$=\{\mathrm{TP} /(\mathrm{TP}+\mathrm{FP})\} \times 100$;

음성 예측치(Negative predictive value, NPV)

$=\{\mathrm{TN} /(\mathrm{TN}+\mathrm{FN})\} \times 100$;

정확도 $=\{(\mathrm{TP}+\mathrm{TN}) /(\mathrm{TP}+\mathrm{TN}+\mathrm{FP}+\mathrm{FN})\} \times 100$,

$\mathrm{k}$ (카파) 분석은 최종 조직병리학적 진단을 기준으로 세포학적 진단, pyrosequencing 분석법, 직접염기서열분석법 그리고 PCR-RFLP 분석법의 측정 오류를 평가하기 위하여 시행하였다 $(\mathrm{k}$ $\geq 0.75$ : excellent, $0.40 \leq \mathrm{k}<0.75$ : fair or good, $\mathrm{k}<0.40$ : poor).

\section{결 과}

\section{1. 세포주를 이용한 $\mathrm{BRAF}^{\mathrm{V} 600 \mathrm{E}}$ 돌연변이 분석 비교}

$\mathrm{BRAF}^{\mathrm{V} 600 \mathrm{E}}$ 돌연변이 검출법의 민감도를 확인하기 위하여, $\mathrm{BRAF}^{\mathrm{V} 600 \mathrm{E}}$ 돌연변이 양성 유두암 세포주 $\mathrm{SNU}-790$ 과 $\mathrm{BRAF}^{\mathrm{V} 600 \mathrm{E}}$
돌연변이 음성 세포주 SNU-216을 이용하여 pyrosequencing 분 석법, 직접 염기서열분석법 그리고 PCR-RFLP 방법으로 분석하였 다. 그 결과 pyrosequencing 분석법에서 돌연변이 양성인 핵산이 야생형 핵산에 계대희석 되었을 때, 'A' 피크의 높이는 'T' 피크의 높이에 비례하여 감소하였다. 즉, $\mathrm{BRAF}^{\mathrm{V} 600 \mathrm{E}}$ 돌연변이 양성인 핵산 의 양에 따라 유의하게 정량화되는 것을 확인하였다(Fig. 1A). 그리 고 돌연변이 검출법의 민감도를 비교하여 분석한 결과, Fig. 1 에서 보는 바와같이, pyrosequencing 분석법은 희석비율이 1 : 99 (1\%) 에서도 $\mathrm{BRAF}^{\mathrm{V} 600 \mathrm{E}}$ 돌연변이가 확인되었지만(Fig. 1A), 직접염기서 열 분석법에서는 $10 \%$ 이상의 돌연변이 핵산이 포함되어야 검출이 가능하였고(Fig. 1B), PCR-RFLP 분석법은 $20 \%$ 이상의 돌연변이 핵산이 포함되어야 돌연변이 검출이 가능하였다(Fig. 1C).

\section{2. $\mathrm{BRAF}^{\mathrm{V} 600 \mathrm{E}}$ 돌연변이 분자진단법의 민감도 및 진단적 가치 비교}

세침흡인 세포검사와 분자진단법의 진단적 가치 평가를 위한 ‘gold standard'는 수술 후 조직병리학적으로 진단되어진 결과로

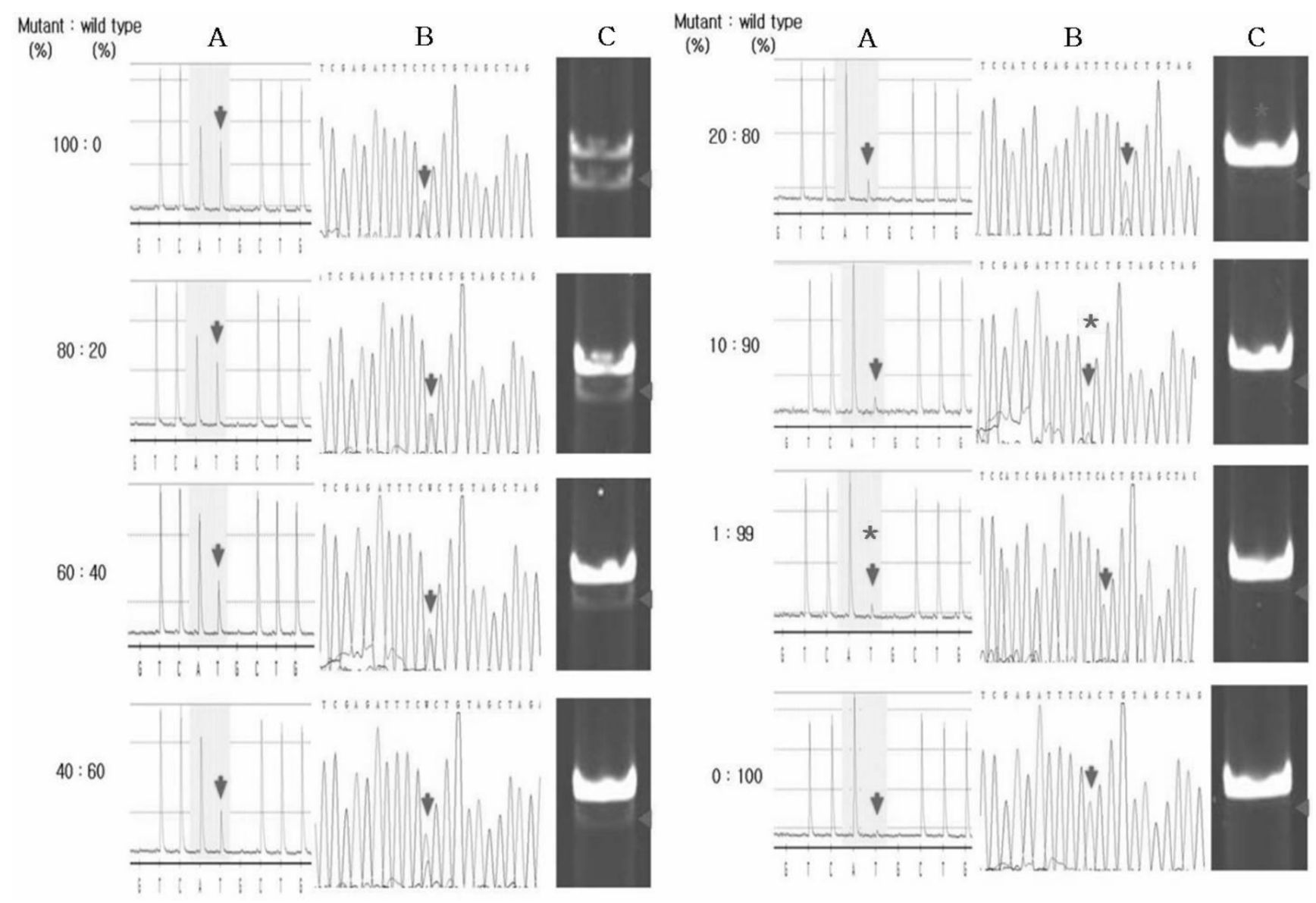

Fig. 1. Results of titration assay assessing the sensitivity of pyrosequencing (A), direct sequencing (B) and PCR-RFLP (C) analysis to detect BRAFV600E mutation. DNA from BRAFV600E mutation-positive heterozygous papillary cell line (SNU-790) was diluted with BRAFV600E mutation -negative stomach cancer cell line (SNU-216) DNA to generate mixtures containing 0 100\% SNU-790 cells. *Lower limit point of BRAF ${ }^{\mathrm{V} 600 \mathrm{E}}$ mutation. 
결정하였고, $\mathrm{BRAF}^{\mathrm{V}}{ }^{600 \mathrm{E}}$ 돌연변이 분자진단법의 진단적 가치평가 는 pyrosequencing 분석법, 직접염기서열 분석법 그리고 PCR-RFLP 분석법에서 각각의 민감도, 특이도, 양성예측도(PPV), 음성예측도 (NPV) 및 정확도를 확인하였다. 그 결과, pyrosequencing 분석법 은 $82.3 \%$ 의 민감도, $94.3 \%$ 의 양성 예측도, $58.5 \%$ 의 음성 예측도 그리고 $91.1 \%$ 의 높은 정확도를 나타냈고, 직접염기서열 분석법과 PCR-RFLP 분석법은 77.2 와 $69.6 \%$ 의 민감도, 88.6 과 $84.8 \%$ 의 정 확도를 보였다. 따라서 세침흡인 세포시료를 이용한 분석에서 pyrosequencing 분석법은 직접염기서열 분석법과 PCR-RFLP 분 석법보다 민감도, 특이도 및 정확도에서 유의하게 우수하였다 ( $p=0.027$ ) (Table 1). 이와 같은 결과는 pyrosequencing 분석법에 서 $\mathrm{BRAF}^{\mathrm{V} 600 \mathrm{E}}$ 돌연변이 양성인 56예의 유두암 세포를 직접염기서 열 분석법과 PCR-RFLP 분석법으로 확인한 결과, 직접염기서열 분 석법은 5\%인 3예에서, PCR-RFLP분석법은 $8.9 \%$ 인 5예에서 $\mathrm{BRAF}^{\mathrm{V} 600 \mathrm{E}}$ 돌연변이 음성으로 나타난 결과로 증명할 수 있었다. Pyrosequencing 분석법에서 $\mathrm{BRAF} \mathrm{V}^{\mathrm{V} 600 \mathrm{E}}$ 돌연변이 음성으로 나타 난 모든 시료는 직접염기서열 분석법이나 PCR-RFLP 분석법에서 도 돌연변이 음성의 결과를 보였다.

또한, 조직병리학적 진단을 기준으로 갑상선암 진단법의 측정 오류 평가를 위한 비교에서, 네 가지 방법의 카파 수치는 0.4 이상으 로 신뢰할 수 있는 진단법이었고, 세침흡인 세포검사는 카파수치가
0.88 로 다른 세 가지 분자진단방법보다 높게 나타났다. 그리고 pyrosequencing 분석법의 카파수치는 0.68 로 직접염기서열분석 법의 0.59이나 PCR-RFLP 분석법의 0.46보다 높게 나타났다 (Table 1).

\section{3. 세침흡인 시료에서 $\mathrm{BRAF}^{\mathrm{V} 600 \mathrm{E}}$ 돌연변이 분석 결과}

갑상선 세침흡인 세포검사 시료를 이용하여 pyrosequencing 분석법에 의한 $\mathrm{BRAF}^{\mathrm{V}}{ }^{600 \mathrm{E}}$ 돌연변이 염기서열의 변화를 보면, 조직 병리학적 진단에 따른 갑상선 결절의 $\mathrm{BRAF}^{\mathrm{V} 600 \mathrm{E}}$ 돌연변이의 발생 률을 pyrosequencing 분석법으로 확인한 결과, 조직학적 진단에 서 악성종양으로 진단된 83예 중 $78.3 \%$ 인 65예에서 $\mathrm{BRAF}^{\mathrm{V} 600 \mathrm{E}}$ 돌 연변이 양성이 관찰되었고, 악성종양 중 유두암으로 진단된 78예 에서는 $83.3 \%$ 인 65 예에서 $\mathrm{BRAF}^{\mathrm{V} 600 \mathrm{E}}$ 돌연변이 양성을 보였다. 그 리고 5예의 소포형 암이나 29예의 양성 결절에서는 BRAF ${ }^{\mathrm{V} 600 \mathrm{E}}$ 돌 연변이가 관찰되지 않았다(Table 2).

\section{4. 불확실한 군에서 $\mathrm{BRAF}^{\mathrm{V}}{ }^{\mathrm{V} 0 \mathrm{E}}$ 돌연변이 유전자 분석 결과}

세침흡인 세포검사에서 불확실한 군으로 분류된 31 예의 갑상선 결절을 조직학적으로 진단 분류한 결과, 28예에서 악성으로 진단 되었고, 1 예의 소포형 선종과 2예의 결절성 과증식증을 포함한 3 예 의 양성 결절로 분류되었다. 그리고 악성으로 진단된 28예의 갑상

Table 1. Comparison of four diagnostic tests to detect thyroid malignancy in thyroid nodules

\begin{tabular}{lcccc}
\hline & $\begin{array}{c}\text { FNAB cytopathology } \\
(\%)\end{array}$ & $\begin{array}{c}\text { Pyrosequencing } \\
\text { analysis (\%) }\end{array}$ & $\begin{array}{c}\text { Direct DNA sequencing } \\
\text { analysis (\%) }\end{array}$ & $\begin{array}{c}\text { PCR-RFLP } \\
\text { analysis (\%) }\end{array}$ \\
\hline Sensitivity* & 100.00 & 82.30 & 77.20 & 69.60 \\
Specificity & 84.80 & 100.00 & 100.00 & 100.00 \\
PPV & 95.20 & 94.30 & 93.90 & 90.30 \\
NPV & 100.00 & 58.50 & 52.30 & 45.10 \\
Accuracy & 92.40 & 91.10 & 88.60 & 84.80 \\
Kappa value $^{\dagger}$ & 0.88 & 0.68 & 0.59 & 0.46 \\
\hline
\end{tabular}

Permanent histologic diagnosis was used as a reference test to calculate each parameter.

*Pyrosequencing analysis was more sensitivity than direct DNA sequencing and PCR-RFLP analysis $(p=0.027) .{ }^{\dagger}$ The kappa value $(k)$ indicated the agreement between four diagnostic methods and the permanent histologic diagnosis.

Table 2. Rates of BRAF ${ }^{\mathrm{V} 600 \mathrm{E}}$ mutation by pyrosequencing in thyroid tumors according to histologic diagnosis

\begin{tabular}{cccc}
\hline & $\begin{array}{c}\text { No. Total } \\
\text { Cases }\end{array}$ & $\begin{array}{c}\text { BRAF } \\
\text { Mutation (+) } \\
\text { Cases }\end{array}$ & $\begin{array}{c}\text { BRAF }^{\mathrm{V} 600 \mathrm{E}} \\
\text { Mutation (+) } \\
\text { Cases (\%) }\end{array}$ \\
\hline Malignancy & 83 & 65 & 78.3 \\
papillary carcinoma & 78 & 65 & 83.3 \\
Follicular carcinoma & 5 & 0 & 0.0 \\
Benign & 29 & 0 & 0.0 \\
Nodular hyperplasia & 23 & 0 & 0.0 \\
Follicular adenoma & 1 & 0 & 0.0 \\
Hashimoto's thyroiditis & 3 & 0 & 0.0 \\
\hline
\end{tabular}

Table 3. BRAF ${ }^{\mathrm{V} 600 \mathrm{E}}$ mutation status by pyrosequencing analysis in nodules with indeterminate FNAB cytology

\begin{tabular}{cccc}
\hline & $\begin{array}{c}\text { No. Total } \\
\text { Cases }\end{array}$ & $\begin{array}{c}\text { BRAF } \\
\text { Mutation (+) } \\
\text { Cases }\end{array}$ & $\begin{array}{c}\text { BRAF }^{\text {Mutantion }} \\
\text { Cases (+) }\end{array}$ \\
\hline Malignancy & 28 & 16 & 57.1 \\
papillary carcinoma & 24 & 16 & 66.7 \\
Follicular carcinoma & 4 & 0 & 0.0 \\
Benign & 3 & 0 & 0.0 \\
Nodular hyperplasia & 2 & 0 & 0.0 \\
Follicular adenoma & 1 & 0 & 0.0 \\
\hline
\end{tabular}


선 결절에는, 24 예의 유두암과 4 예의 소포형 암을 포함하고 있었 다. 또한 세침흡인 세포검사에서 불확실한 군으로 진단 분류된 시 료를 pyrosequencing 분석법으로 $\mathrm{BRAF}^{\mathrm{V} 600 \mathrm{E}}$ 돌연변이를 확인한 결과, 24예의 유두암 중 66.7\%인 16예에서 전형적인 유두암에 존 재하는 $\mathrm{BRAF}{ }^{\mathrm{V} 600 \mathrm{E}}$ 돌연변이가 확인되었고, 1 예의 소포형 선종과 2 예의 결절성 과증식증을 포함한 3예의 양성결절에서는 $\mathrm{BRAF}^{\mathrm{V} 600 \mathrm{E}}$ 돌연변이가 관찰되지 않았다(Table 3).

\section{고 찰}

최근 갑상선암의 감별과 세침흡인 세포검사의 불확실한 진단을 보완하기 위하여 갑상선 유두암 유발에 관련된 $\mathrm{BRAF}^{\mathrm{V} 600 \mathrm{E}}$ 돌연변 이 유전자를 진단 표지자로 적용하려는 연구가 추진되고 있다 (Jarry et al., 2004; Kim et al., 2004; Kim et al., 2006; Kim et al., 2008; Chung et al., 2006). $\mathrm{BRAF}^{\mathrm{V} 600 \mathrm{E}}$ 돌연변이에 대한 선행 연구 결과를 살펴보면, 갑상선 유두암에서 Chung 등(2006)은 $86 \%$, $\operatorname{Kim}$ 등(2004)은 83\% 그리고 $\operatorname{Kim}$ 등(2006)은 73.4\%의 BRAF ${ }^{\mathrm{V} 600 \mathrm{E}}$ 돌연변이 양성을 보였고, $\mathrm{BRAF}^{\mathrm{V} 600 \mathrm{E}}$ 유전자가 갑상선 유두암 진단 표지자로 유용하다고 보고하였다. 본 연구에서도 조직학적 검사에 의해 결과가 확인된 갑상선 세침흡인 세포검사 시료를 이용하여 $\mathrm{BRAF}^{\mathrm{V} 600 \mathrm{E}}$ 돌연변이 여부를 분석한 결과, 갑상선암으로 확인된 세 포에서 $78.3 \%$ 의 $\mathrm{BRAF}^{\mathrm{V} 600 \mathrm{E}}$ 돌연변이 양성을 보였고, 갑상선암 중 유두암으로 분류된 세포에서는 $83.3 \%$ 의 $\mathrm{BRAF}^{\mathrm{V} 600 \mathrm{E}}$ 돌연변이 양성 이 관찰되어(Table 2), 선행한 연구자들의 결과와 유사한 결과가 측 정되었다. 따라서 $\mathrm{BRAF}^{\mathrm{V}}{ }^{600 \mathrm{E}}$ 유전자는 갑상선암 진단 표지자로서 적용이 가능하고, 특히 갑상선 유두암의 발생빈도가 높은 한국인의 갑상선암 감별 진단에 유용한 유전자인 것으로 생각된다.

$\mathrm{Kim}$ 등(2006)은 갑상선 세침흡인 세포검사의 불확실한 진단은 임상의사의 최종 진단에 혼동을 주고, Haugen 등(2002), Oertel 등(2002)은 불필요한 외과적 수술 이환율이 증가하는 문제점을 제 시하였다. 따라서 이들 연구자들은 문제점의 해결을 위하여 불확실 한 군으로 분류된 갑상선 세포로 분자유전학적인 $\mathrm{BRAF}^{\mathrm{V} 600 \mathrm{E}}$ 돌연 변이 유전자에 대한 연구를 선행하였다. 그 결과, Kim 등(2006)은 $60 \%, \operatorname{Kim}$ 등(2008)은 $72.2 \%$ 의 BRAF ${ }^{\mathrm{V} 600 \mathrm{E}}$ 돌연변이 양성을 확인 하였고, 돌연변이가 존재하는 세포를 갑상선 유두암 타입으로 분류 하였다. 본 연구에서도 갑상선 세침흡인 세포검사에서 불확실한 군 으로 분류된 31예를 이용하여 $\mathrm{BRAF}{ }^{\mathrm{V} 600 \mathrm{E}}$ 돌연변이 여부를 분석한 결과, 조직학적 검사에서 갑상선 유두암으로 분류된 28예 중, $66.7 \%$ 인 16예가 $\mathrm{BRAF}^{\mathrm{V} 600 \mathrm{E}}$ 돌연변이 양성을 보여, 선행한 연구자 들과 유사한 결과를 확인할 수 있었다(Table 3). 따라서 $\mathrm{BRAF}^{\mathrm{V} 600 \mathrm{E}}$ 돌연변이 유전자는 갑상선 유두암 감별진단 표지자로 유용하다고
사료되며, 또한 세포검사의 불확실한 진단에 대한 문제점을 보완하 기 위하여, 세침흡인 세포검사와 $\mathrm{BRAF}^{\mathrm{V} 600 \mathrm{E}}$ 돌연변이 분자진단검 사의 병행이 필요하다고 생각된다.

$\mathrm{BRAF}^{\mathrm{V} 600 \mathrm{E}}$ 돌연변이 분석을 위한 분자 진단검사법으로 다양한 분자생물학적방법이 적용되어 왔으며, 직접염기서열 분석법과 PCR-RFLP 분석법은 보편적으로 이용되고 있는 분석법이다. 그러 나 본 연구는 Agaton 등(2002)이 언급한 새로운 염기서열 분석법 인 pyrosequencing 분석법이 $\mathrm{BRAF}^{\mathrm{V} 600 \mathrm{E}}$ 돌연변이 분석에 유용할 것으로 생각되어, 상술한 두 방법간의 민감도와 정확도를 비교하였 다. Pyrosequencing 분석법의 민감도 확인을 위하여 $\mathrm{BRAF}^{\mathrm{V} 600 \mathrm{E}}$ 돌연변이가 존재하는 세포주로 직접염기서열 분석법 및 PCR-RFLP 분석법간의 민감도를 비교 분석한 결과, $20 \%$ 이상의 돌연변이체가 포함된 시료에서는 세 가지 방법 모두 $\mathrm{BRAF}^{\mathrm{V} 600 \mathrm{E}}$ 돌연변이를 정확 하게 확인할 수 있었으나, $10 \%$ 미만의 돌연변이체가 포함된 시료 에서는 pyrosequencing 분석법은 $\mathrm{BRAF}^{\mathrm{V} 600 \mathrm{E}}$ 돌연변이가 정확히 확인되었고, 직접염기서열 분석법과 PCR-RFLP 분석법에서는 돌 연변이가 나타나지 않았다(Fig. 1). 이와 같은 결과는 Mane 등 (1990)이 제기한 직접염기서열 분석법과 PCR-RFLP 분석법은 분 석시간이 길고, $20 \sim 25 \%$ 이상의 돌연변이 유전자가 포함되어야 정확한 변이 분석이 가능하다는 연구결과를 뒷받침하고, pyrosequencing 분석법의 우수성을 확인할 수 있는 결과라고 사 료된다. 따라서 pyrosequencing 분석법은 $\mathrm{BRAF}^{\mathrm{V} 600 \mathrm{E}}$ 돌연변이 분 석에서 직접염기서열 분석법과 PCR-RFLP 분석법보다 민감도가 높은 분석법이며, 직접염기서열 분석법과 PCR-RFLP 분석법의 단 점을 보완 할 수 있는 유용한 분자진단 검사법으로 생각된다.

$\mathrm{BRAF}^{\mathrm{V} 600 \mathrm{E}}$ 돌연변이 분석을 위한 진단검사법의 정확도 평가 결 과를 보면, pyrosequencing 분석법은 $82.3 \%$ 의 민감도와 $94.3 \%$ 의 양성 예측도(PPV), $58.5 \%$ 의 음성 예측도(NPV) 그리고 $91.1 \%$ 의 정확도를 보인 반면, 직접염기서열 분석법과 PCR-RFLP 분석법은 77.2 와 $69.6 \%$ 의 민감도, 88.6 과 $84.8 \%$ 의 정확도를 보였다 ( $p=0.027$ ) (Table 1). 이러한 pyrosequencing 분석법의 높은 민감 도와 정확도는 $\mathrm{BRAF}^{\mathrm{V} 600 \mathrm{E}}$ 돌연변이 양성으로 밝혀진 56예의 유두 암 세포를 분석한 결과, pyrosequencing 분석법은 56예 모든 시료 에서 $\mathrm{BRAF} \mathrm{F}^{\mathrm{V} 60 \mathrm{E}}$ 돌연변이 양성을 나타냈고, 직접염기서열 분석법 은 5\%인 3예, PCR-RFLP 분석법은 8.9\%인 5예에서 $\mathrm{BRAF}^{\mathrm{V} 600 \mathrm{E}}$ 돌 연변이 음성으로 나타난 연구결과로 확인할 수 있었다. 따라서 pyrosequencing 분석법은 $\mathrm{BRAF}^{\mathrm{V} 600 \mathrm{E}}$ 돌연변이 분석에서 보편적 으로 사용되고 있는 두 방법 보다 민감하고 정확한 분자진단 검사 법이라고 사료된다.

결론적으로, 본 연구 결과들은 갑상선암에서 $\mathrm{BRAF}^{\mathrm{V}}{ }^{\mathrm{V}} \mathrm{E}$ 돌연변 이 유전자는 갑상선 유두암 감별 진단에 유용하고, 불확실한 세침 
흡인 세포검사의 단점을 보완 할 수 있는 매우 유용한 진단 표지자 라는 것을 확인하여 주었다. 그리고 $\mathrm{BRAF}^{\mathrm{V} 600 \mathrm{E}}$ 돌연변이 분석법 비 교에서는 pyrosequencing 분석법이 기존의 다른 방법들 보다 정 확도가 높은 분석법으로 확인되었다.

\section{Acknowledgements: None}

Funding: None

Conflict of interest: None

\section{References}

1. Agaton C, Unneberg P, Sievertzon M, Holmberg Aehn M, Larsson M, Odeberg J, Uhlén M. Gene expression analysis by signature pyrosequencing. Gene. 2002; 289:3-39.

2. Ahmadian A, Gharizadeh B, Gustafsson AC. Single-nucleotide polymorphism analysis by pyrosequencing. Anal Biochem. 2000, 280:103-110.

3. Chung KW, Yang SK, Lee GK, Kim EY, Kwon S, Kim SW. Detection of $\mathrm{BRAF}^{\mathrm{V} 600 \mathrm{E}}$ mutation on fine needle aspiration specimens of thyroid nodule refines cyto-pathology diagnosi, especially in $\mathrm{BRAF}^{\mathrm{V} 600 \mathrm{E}}$ mutation-prevalent area. Clin Endocrinol. 2006, 65:660-666.

4. Chung JH, Hahm JR, Min YK, Lee MS, Lee MK, Kim KW, Nam SJ, Yang JH, Ree HJ. Detection of RET/PTC oncogene rearrangement in Korean papillary thyroid carcinomas. Thyroid. 1999, 9:1237-1243.

5. Davies H, Bignell GR, Cox C, Stephens P, Edkins S, Clegg S, Teague J., Woffendin H., Garnett MJ, Bottomley W, Davis N. Mutations of the BRAF gene in human cancer. Nature. 2002, 417:949-954.

6. Ezzat S, Sarti DA, Cain DR, Braunstein GD. Thyroid incidentalomas. Prevalence by palpation and ultrasonography. Arch Intern Med. 1994, 154:1838-1840.

7. Fakhrai-Rad H, Pourmand N, Ronaghi M. Pyrosequencing: an accurate detection platform for single nucleotide polymorphisms. Hum Mutat. 2002, 19:479-485.

8. Fukushima T, Suzuki S, Mashiko M, Ohtake T, Endo Y, Takebayashi Y, Sekikawa K, Hagiwara K. BRAF mutations in papillary carcinomas of the thyroid. Oncogene. 2003, 22: 6455-6457.

9. Garcia CA, Ahmadian A, Gharizadeh B, Lundeberg J, Ronaghi M. Mutation detection by pyrosequencing: sequencing of exons 5-8 of the p53 tumor suppressor gene. Gene. 2000, 253:249-257.

10. Haugen BR, Woodmansee WW, McDermott MT. Towards improving the utility of fine needle aspiration biopsy for the diagnosis of thyroid tumors. Clin Endocrinol. 2002, 56:281-290.

11. Hayashida N, Namba H, Kumagai A, Hayashi T, Ohtsuru A, Ito M, Saenko VA, Maeda S, Kanematsu T, Yamashita S.A rapid and simple detection method for the BRAF (T1796A) mutation in fine-needle aspirated thyroid carcinoma cells. Thyroid. 2004, 14:910-915.

12. Hilger RA, Scheulen ME, Strumberg D. The Ras-Raf-MEK-ERK pathway in the treatment of cancer. Onkologie. 2002, 25:511-518.
13. Jarry M, Masson D, Cassagnau E, Parois S, Laboisse C, Denis MG. Real time allele- specific amplification for sensitive detection of BRAF mutation V600E. Mol Cell Probes. 2004, 18:349-352.

14. Jin L, Sebo TJ, Nakamura N, Qian X, Oliveira A, Majerus JA, Johnson MR, Lloyd RV. BRAF mutation analysis in fine needle aspiration (FNA) cytology of the thyroid. Diagn Mol Pathol. 2006, 15:136-143.

15. Kang KW, No JH, Chung JH. Prevalence, clinical and ultrasonographic characteristics of thyroid incidentalomas. Thyroid. 2004, 14:29-33.

16. Kim K, Kang D, Kim S, Seong IO, Kang D. Mutations of BRAF gene in papillary thyroid carcinoma in a Korean population. Yonsei Med J. 2004, 45:818-821.

17. Kim TY, Kim WB, Song JY, Rhee YS, Gong G, Cho YM, Kim SY, Kim SC, Hong SJ, Shong YK. The BRAF ${ }^{\mathrm{V} 600 \mathrm{E}}$ mutation is useful for prediction of clinical recurrence in low-risk patients with conventional papillary thyroid carcinoma. Clin Endocrinol. 2006, 65:364-368.

18. Kim SK, Kim DL, Han HS, Kim WP, Kim SJ, Moon WJ, Oh SY Hwang TS. Pyrosequencing analysis for detection of a $\mathrm{BRAF}^{\mathrm{V} 600 \mathrm{E}}$ mutation in an FNAB specimen of thyroid nodules. Diagn Mol Pathol. 2008, 17:118-125.

19. Kimura ET, Nikiforova MN, Zhu Z, Knauf JA, Nikiforov YE, Fagin JA. High prevalence of BRAF mutations in thyroid cancer: genetic evidence for constitutive activation of the RET/ PTC-RAS-BRAF signaling pathway in papillary thyroid carcinoma. Cancer Res. 2003, 63:1454-1457.

20. Lee HK, Hur MH, Ahn SM. Diagnosis of occult thyroid carcinoma by ultrasonography. Yonsei Med J. 2003, 44:1040-1044.

21. Mane SM, Meltzer SJ, Gutheil JC. RAS gene activation in acute myelogenous leukemia: analysis by in vitro amplification and DNA base sequence determination. Genes Chromosomes Cancer. 1990, 2:71-77.

22. Meier CA. Thyroid nodules: pathogenesis, diagnosis and treatment. Baillieres Best Pract Res Clin Endocrinol Metab. 2000, 14:559-575.

23. National Cancer Centre, Korea. 2002 Annual Report of the Korea Central Cancer Registry. 2003.

24. Oertel YC. A pathologist trying to help endocrinologist to interpret cytopathology reports from thyroid aspirates. J Clin Endocrinol Metab. 2002, 87:1459-1461.

25. Oertel YC, Burman K, Boyle L, Ringel M, Wartofsky L, Shmookler B, Yeganeh F, Nostrand DV. Integrating fine-needle aspiration into a daily practice involving thyroid disorders: the Washington Hospital Center Approach. Diag Cytopathol. 2002, 27:120-122.

26. Oh SY, Han JY, Lee SR Lee HT. Improved DNA Extraction Method for Molecular Diagnosis from Smaller numbers of Cells. Korean J Clin Lab Sci. 2014, 46(3):99-105

27. Peyssonnaux C, Eychene A. The Raf/MEK/ERK pathway: new concepts of activation. Biol Cell. 2001, 93:53-62.

28. Xing, M. BRAF mutation in thyroid cancer. Endocr Relat Cancer. 2005, 12:245-262.

29. Pak SI, Koo HS, Hwang CY, Youn HY. Application of Receiver Operating Characteristics (ROC) Curves for Clinical Diagnostic Tests. J Vet Clin. 2002, 19:312-315. 